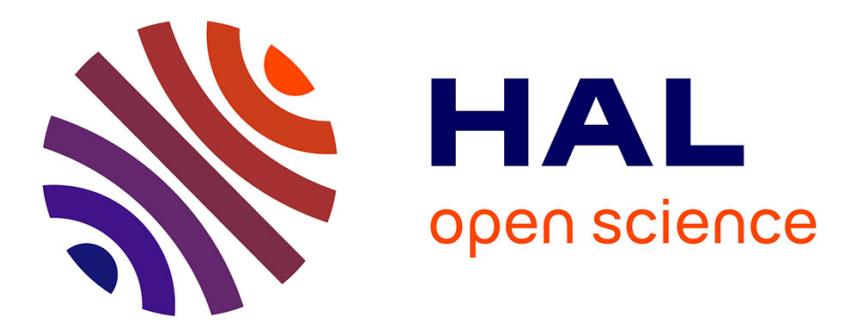

\title{
Radiochemical ageing of epoxy coating for nuclear plants
}

D. P.R. Queiroz, Frédéric Fraïsse, Bruno Fayolle, Matthias Kuntz, Jacques

\author{
Verdu
}

\section{To cite this version:}

D. P.R. Queiroz, Frédéric Fraïsse, Bruno Fayolle, Matthias Kuntz, Jacques Verdu. Radiochemical ageing of epoxy coating for nuclear plants. Radiation Physics and Chemistry, 2010, 79 (3), pp.362364. 10.1016/j.radphyschem.2009.08.034 . hal-02270045

\section{HAL Id: hal-02270045 \\ https://hal.science/hal-02270045}

Submitted on 23 Aug 2019

HAL is a multi-disciplinary open access archive for the deposit and dissemination of scientific research documents, whether they are published or not. The documents may come from teaching and research institutions in France or abroad, or from public or private research centers.
L'archive ouverte pluridisciplinaire HAL, est destinée au dépôt et à la diffusion de documents scientifiques de niveau recherche, publiés ou non, émanant des établissements d'enseignement et de recherche français ou étrangers, des laboratoires publics ou privés. 


\title{
Radiochemical ageing of epoxy coating for nuclear plants
}

\author{
D.P.R. Queiroz ${ }^{\text {a }}$, F. Fraïsse ${ }^{\text {a }}$, B. Fayolle ${ }^{\mathrm{a}, *}$, M. Kuntz ${ }^{\mathrm{b}}$, J. Verdu ${ }^{\mathrm{a}}$ \\ a Laboratoire d'Ingénierie des Matériaux (UMR 8006), Arts et Métiers Paristech, 151 Boulevard de l'Hôpital, 75013 Paris, France \\ ${ }^{\mathrm{b}}$ EDF REDD, Département Matériaux et Mécanique des Composants, Avenue des Renardières, Ecuelles, 77250 Moret sur Loing, France
}

\section{A R T I C L E I N F O}

Keywords:

Epoxy network

Radiochemical ageing

Structure characterization

\begin{abstract}
A B S T R A C T
The degradation of an epoxy-amine network exposed to gamma irradiation in oxygen atmosphere has been studied by using a variety of analytical methods, including infrared spectroscopy (FTIR), differential scanning calorimetry (DSC), and sol-gel analysis. Results show that the oxidation of epoxy systems grows with the irradiation dose. Hydroperoxides, which are species resulting from oxidation, were identified and quantified by DSC. As indicated by the sol-gel analysis, the mechanism of degradation of chain scission seems to be predominant over crosslinking. The modifications induced by irradiation reflect in a greater capacity of water absorption.
\end{abstract}

\section{Introduction}

Networks based on poly(amidoamine) cured aromatic diepoxides are used as coatings, paints, etc. in wide variety of applications including nuclear plants (Park et al., 2004; Lee et al., 2006). In the latter case, indeed, durability is a key property. An important ageing component is, presumably, radiochemical ageing induced by low dose rate irradiation in the presence of oxygen. Several studies have been reported in the literature (Damian et al., 2001; Ngono-Ravache et al., 2001; Devanne et al., 2005; Longiéras et al., 2006; Longiéras et al., 2007) concerning the degradation of epoxy systems but this subject is not completely understood. In this work, we investigated the radio-oxidation of epoxy-amine network prepared from diglycidylether of bisphenol A (DGEBA) and a poly(amidoamine). This material was exposed to gamma irradiation under oxygen atmosphere. The characterization of the polymer oxidation was made using several methods ranging from molecular scale to macromolecular one such as solgel analysis, differential scanning calorimetry, IR spectrophotometry and density.

\section{Experimental}

\subsection{Materials and methods}

The studied epoxy network was based on a diglycidylether of bisphenol A (DGEBA), Araldite PZ 756/67, and a polyamidoamine,
Aradur 435. The structure of polyamidoamine is given in Fig. 1. The amine/epoxy functional ratios of this network are equal to 0.86 and the film thickness is close to $70 \mu \mathrm{m}$.

Irradiations were carried out in an atmosphere of oxygen at $50{ }^{\circ} \mathrm{C}$ with a dose rate of $200 \mathrm{~Gy} / \mathrm{h}$. Five doses in the range from 0 to $60 \mathrm{kGy}$ were studied. Samples were stored at $-10^{\circ} \mathrm{C}$ in order to limit post-degradation.

Infrared spectrophotometric measurements were carried out on the films by using a Bruker IFS 28 spectrometer in the transmission mode.

Differential scanning calorimetry (DSC) was performed using a TA Q10-0553 equipment. The analysis was realized by heating the samples from 0 to $180^{\circ} \mathrm{C}$ at $10^{\circ} \mathrm{C} / \mathrm{min}$ under nitrogen, followed by a cooling to $0^{\circ} \mathrm{C}$ at $20^{\circ} \mathrm{C} / \mathrm{min}$ and a second heating under the same conditions as the first run. In aged samples, an exotherm appears close to $150^{\circ} \mathrm{C}$. Its enthalpy $\Delta H_{\mathrm{Tm}}$ was directly determined by peak integration. The glass transition temperature $\left(T_{\mathrm{g}}\right)$ was obtained from the second run. All experiments are repeated twice.

Sulfur dioxide treatment was used to destroy hydroperoxides. $\mathrm{SO}_{2}$ was generated by a solution of $\mathrm{Na}_{2} \mathrm{SO}_{3}$ and $\mathrm{HCl}$. Treatments were performed for $5 \mathrm{~h}$ at $60{ }^{\circ} \mathrm{C}$ and their consequence on the exotherm at $150^{\circ} \mathrm{C}$ was checked by DSC. The sol fraction of the films was determined by Soxhlet extraction using THF for $5 \mathrm{~h}$. The sol content is provided by the difference in weight before and after the extraction operation.

The density of films was determined by a Mohr balance. The weights of the samples were measured in the air and after immersion in water bath. The density $\rho$ is calculated by the following equation:

$\rho=\frac{A}{|B-A|_{*}} \rho_{\text {water }}$,

\footnotetext{
* Corresponding author. Tel.: +330144246149; fax: +330142169213

E-mail address: bruno.fayolle@paris.ensam.fr (B. Fayolle).
} 
where $A$ and $B$ are the weights of the films in dry state and immersed in the water, respectively, and $\rho_{\text {water }}$ is the water density.

The sorption and desorption characteristics of epoxy films have been measured by dynamic vapour sorption, using the gravimetric DVS measurements surface systems, at $50{ }^{\circ} \mathrm{C}$ and relativity humidity of $70 \%$. Diffusion coefficient is calculated from mass changes assuming that the sorption mechanism follows a Fickian behaviour.

\section{Results and discussion}

The IR spectra of the carbonyl region for the epoxy films irradiated to different doses are shown in Fig. 2a. One can notice a band centered at $1730 \mathrm{~cm}^{-1}$ for all samples assigned to carbonyl stretching. The intensity of this band increases with the irradiation dose and it is associated with the formation of oxidation products, such as ketones, carboxylic acids, esters or formates. The absorbance at $1730 \mathrm{~cm}^{-1}$ was scaled according to an internal reference at $1886 \mathrm{~cm}^{-1}$ whose intensity is invariant throughout degradation (Fig. 2a). The carbonyl concentration was determined by using the Beer-Lambert law in which the molar absorptivity usual value is $300 \mathrm{~L} \mathrm{~mol}^{-1} \mathrm{~cm}^{-1}$ for carbonyl group. The carbonyl concentrations are presented in Fig. $2 \mathrm{~b}$ as a function of irradiation dose. One can see that carbonyl concentration increases linearly with the irradiation dose at a rate of $16 \times 10^{-6} \mathrm{~mol} \mathrm{~Gy}^{-1}$. The DSC results and the thermograms (1st run) for the irradiated and non-irradiated epoxy films are shown in Table 1 and Fig. 3a, respectively. The second run, not included in figures, shows that the $T_{\mathrm{g}}$ of the samples exposed to different irradiation dose is almost dose independent close to $60^{\circ} \mathrm{C}$. The fact that irradiation does not induce a significant $T_{\mathrm{g}}$ change is not very surprising in such networks based on chains of relatively low stiffness. Endotherms close to $T_{\mathrm{g}}$ are observed only in the 1 st run. They may indicate the existence of a structural relaxation process, associated to physical ageing, that is not surprising considering the proximity of the ageing temperature with $T_{\mathrm{g}}$. But the most important feature is that the exothermic peak at around $150{ }^{\circ} \mathrm{C}$ that appears for the samples with irradiation dose up to $20 \mathrm{kGy}$. This exotherm increases with the irradiation dose.

$$
\begin{gathered}
\mathrm{H}_{2} \mathrm{~N}-\mathrm{R}^{\prime}-\mathrm{NH}+\underset{\mathrm{O}}{\mathrm{C}}-\mathrm{R}-\mathrm{C}-\mathrm{NH}-\mathrm{R}^{\prime}-\mathrm{NH} \underset{\mathrm{m}}{\mathrm{H}} \\
\mathrm{R}=\left(\mathrm{CH}_{2}\right)_{6} \text { and } \mathrm{R}^{\prime}=\left(\mathrm{CH}_{2}\right)_{8}
\end{gathered}
$$

Fig. 1. Chemical structure of the polyamidoamine.
The exothermic peak can be associated to hydroperoxide decomposition. As a matter of fact, $\mathrm{SO}_{2}$ treatment, which is well known to destroy hydroperoxides by non-radical process, induces the disappearance of this peak (Carlsson et al., 1986; Gardette and Lemaire, 1986). The thermograms of a treated and a non-treated irradiated sample are shown in Fig. 3b: the exotherm at $150{ }^{\circ} \mathrm{C}$ disappears after the $\mathrm{SO}_{2}$ treatment.

Richaud et al. (2006) have used the same technique, $\mathrm{SO}_{2}$ treatment and DSC, for the hydroperoxide characterization to study polypropylene thermo-oxidation. They used the heat of the exothermic peak, appeared at around $150^{\circ} \mathrm{C}$, to calculate the hydroperoxide concentration. Mallégol et al. (2001) also have attributed an exotherm in alkyd resins to peroxide thermal decomposition. The temperature of this exotherm has changed from 121 to $171^{\circ} \mathrm{C}$ with the oxidation time. Ouldmetidji et al. (2001) have used DSC for the quantification of peroxide concentration in polystyrene and elastomeric materials. For epoxy systems, the use of DSC method for the characterization of hydroperoxides has never been reported to our knowledge.

By assuming that proportionality between decomposition enthalpy $\left(\Delta H\right.$ in $\left.\mathrm{Jg}^{-1}\right)$ and hydroperoxide concentration $(\Delta[\mathrm{POOH}]$ in $\left.\mathrm{mol} \mathrm{kg}^{-1}\right)$ is the same as in the case of polypropylene, i.e. $325 \mathrm{~kJ} \mathrm{~mol}^{-1}$ of $\mathrm{POOH}$, hydroperoxide concentration can be calculated by using the following equation (Richaud et al., 2006):

$$
\Delta[\mathrm{POOH}]=\Delta H / 325
$$

This statement is based on the fact that the temperature of hydroperoxide decomposition found in our epoxy network and in polypropylene reported is similar, that may indicate some similarity in thermochemical characteristics.

The calculated hydroperoxide concentrations are shown in Fig. 4 , as a function of the irradiation dose. This graph displays an induction period corresponding to a radiation dose of $17.5 \mathrm{kGy}$, or a period of $87 \mathrm{~h}$ of irradiation at a dose rate of $200 \mathrm{~Gy} / \mathrm{h}$. After the end of the induction period, the hydroperoxide concentration increases almost linearly with the dose. Using these values, one can assess a radiochemical yield for hydroperoxide. It appears that in our case this yield is close to 4 groups $/ 100 \mathrm{eV}$, a usual order of magnitude in polymer radiochemistry.

Table 1

DSC results for epoxy films irradiated to different irradiation doses.

\begin{tabular}{llll}
\hline Irradiation dose $(\mathrm{kGy})$ & $T_{\mathrm{g}}\left({ }^{\circ} \mathrm{C}\right)$ & $T_{\text {peak }}\left({ }^{\circ} \mathrm{C}\right)$ & $\Delta H_{\text {Tpeak }}(\mathrm{J} / \mathrm{g})$ \\
\hline 0 & 57 & - & - \\
10 & 57 & - & - \\
20 & 58 & 157 & 0.3 \\
40 & 58 & 151 & 2.7 \\
60 & 60 & 149 & 5.3 \\
\hline
\end{tabular}

b

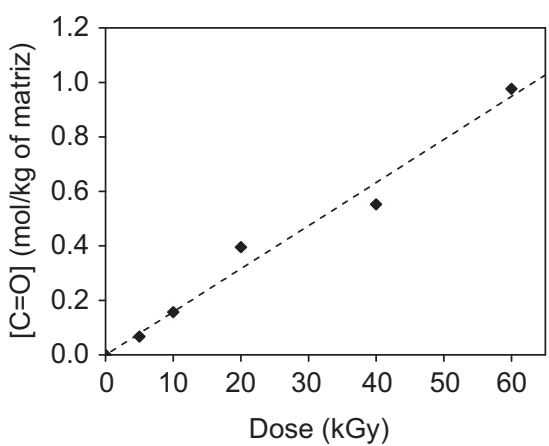

Fig. 2. (a) $2000-1650 \mathrm{~cm}^{-1}$ region of IR spectra of epoxy films irradiated at different doses and (b) increase in the concentration of carbonyl as a function of dose. 

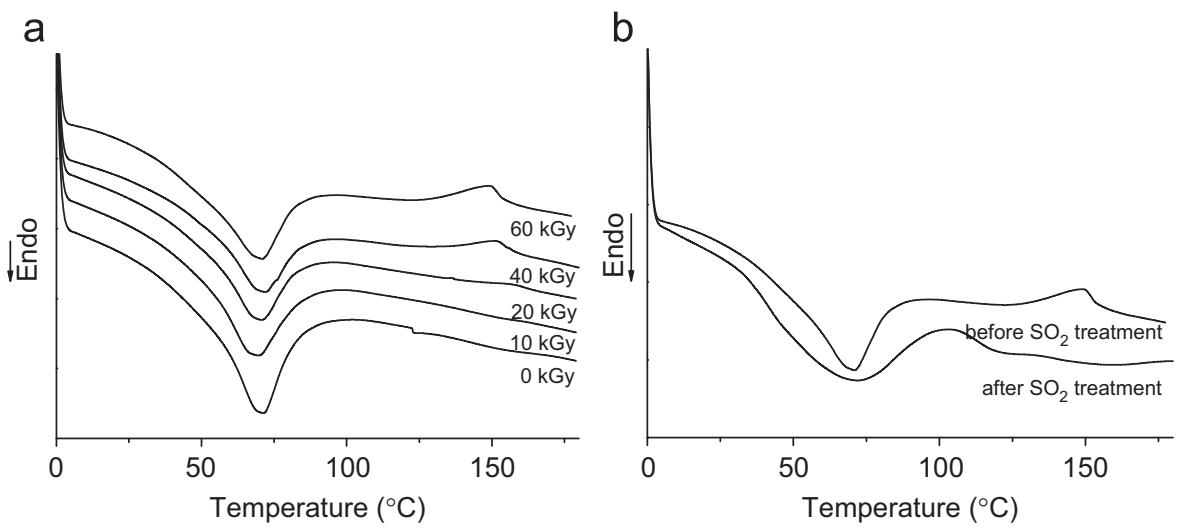

Fig. 3. (a) DSC thermograms of epoxy films irradiated to different doses and (b) thermograms of irradiated samples ( $60 \mathrm{kGy})$ before and after $\mathrm{SO}_{2}$ treatment.

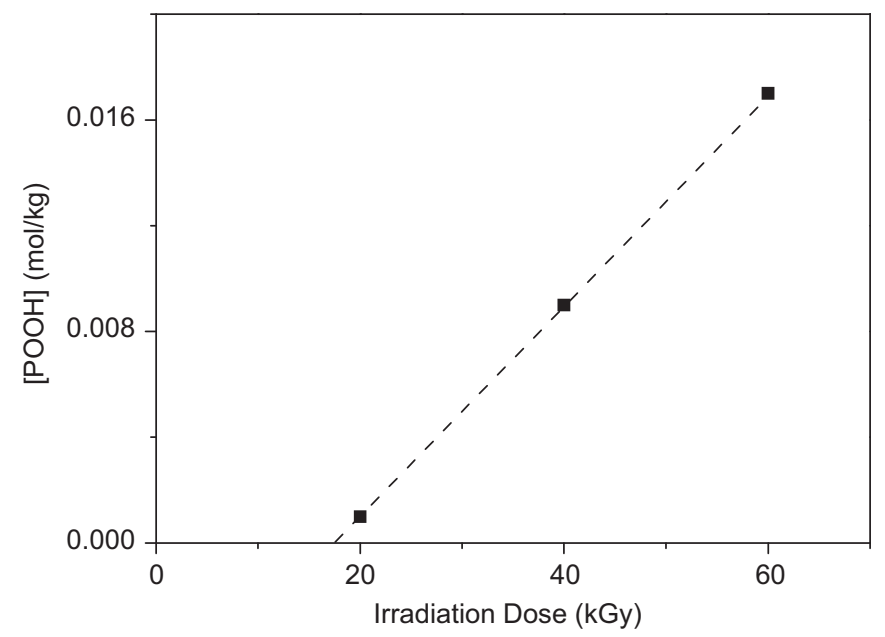

Fig. 4. Hydroperoxide concentration versus irradiation dose for irradiated epoxy films.

The sol fraction increases as a function of absorbed dose: a sol fraction value close to $13 \%$ is reached after $60 \mathrm{kGy}$ irradiation whereas the initial value before irradiation was close to $7 \%$. This significant increase seems to indicate that chain scission predominates over crosslinking in our case.

Water sorption tests reveal a small but significant increase of the equilibrium water uptake: $3.82 \%$ after $60 \mathrm{kGy}$ exposure against $3.46 \%$ before ageing. This increase can be linked to the presence of highly hydrophilic carboxylic acids and amides among carbonyls observed by IR. More significant is the decrease in diffusivity from $2.06 \times 10^{-12} \mathrm{~m}^{2} \mathrm{~s}^{-1}$ before ageing to $1.27 \times 10^{-12} \mathrm{~m}^{2} \mathrm{~s}^{-1}$ after $60 \mathrm{kGy}$ exposure. This would be consistent with the results of Thominette et al. (2006) showing that water diffusivity is a decreasing function of hydrophilicity in many polymer families among which amine crosslinked epoxies.

\section{References}

Carlsson, D.J., Brousseau, R., Wiles, D.W., 1986. Reactions of sulfur dioxide with oxidized polyolefins. Polym. Degrad. Stab. 15, 67-79.

Damian, C., Espuche, E., Escoubes, M., 2001. Influence of three ageing types (thermal oxidation, radiochemical and hydrolytic ageing) on the structure and gas transport properties of epoxy-amine networks. Polym. Degrad. Stab. 72, $447-458$.

Devanne, T., Bry, A., Raguin, N., Sebban, M., Palmas, P., Audouin, L., Verdu, J., 2005. Radiochemical ageing of an amine cured epoxy network. Part II: kinetic modelling. Polymer 46, 237-242.

Gardette, J.L., Lemaire, L., 1986. Advantages and limits of hydroperoxide titration methods in solid polymers. Polym. Photochem. 7, 409-416.

Lee, J.R., Park, S.J., Seo, M.K., Baik, Y.K., Lee, S.K., 2006. A study on physicochemical properties of epoxy coating system for nuclear power plants. Nucl. Eng. Des. 236, 931-937.

Longiéras, N., Sebban, M., Palmas, P., Rivaton, A., Gardette, J.L., 2007. Degradation of epoxy resins under high energy electron beam irradiation: radio-oxidation. Polym. Degrad. Stab. 92, 2190-2197.

Longiéras, N., Sebban, M., Palmas, P., Rivaton, A., Gardette, J.L., 2006. Multiscale approach to investigate the radiochemical degradation of epoxy resins under high-energy electron-beam irradiation. J. Polym. Sci.: Polym. Chem. 44, 865-887.

Mallégol, J., Gonon, L., Commereuc, S., Verney, V., 2001. Thermal (DSC) and chemical (iodometric titration) methods for peroxides measurements in order to monitor drying extent of alkyd resins. Prog. Org. Coat. 41, 171-176.

Ngono-Ravache, Y., Foray, M.F., Bardet, M., 2001. High resolution solid-state ${ }^{13} \mathrm{C}$-NMR study of as-cured and irradiated epoxy resins. Polym. Adv. Technol. $12,515-523$.

Ouldmetidji, Y., Gonon, L., Commereuc, S., Verney, V., 2001. A differential scanning calorimetry method to study polymer photoperoxidation. Polym. Test. 20, 765-768.

Park, S.J., Seo, M.K., Lee, J.R., 2004. Effects of irradiation and design basis accident conditions on thermal properties of epoxy coating system for nuclear power plant. Nucl. Eng. Des. 228, 47-54

Richaud, E., Farcas, F., Fayolle, B., Audouin, L., Verdu, J., 2006. Hydroperoxide titration by DSC in thermally oxidized polypropylene. Polym. Test. 25, 829838.

Thominette, F., Gaudichet-Maurin, E., Verdu, J., 2006. Effect of structure on water diffusion in polymers. Defect and Diffusion Forum 258, 442-446. 